\title{
A imagem na arte verbal Maxakali: aspectos de uma poética de pajelança
}

\author{
Charles A. P. Bicalho' \\ I - UEMG \\ Cláudio (MG), Brasil
}

Resumo: Investigação sobre a imagem na arte verbal dos Maxakali ou Tikmû'ûn, índios que vivem em quatro territórios no estado de Minas Gerais, falam a língua Maxakali, do tronco linguístico Macro-Gê. Com base num dos aspectos centrais da espiritualidade Maxakali a transformação post mortem do koxuk (palavra, alma) em yãmîy (canto, espírito) - e em manifestações artístico-midiáticas típicas de seus rituais, conectadas ao pano de fundo mitológico, reconhecemos no trato da imagem uma das potências responsáveis pela criação e preservação de suas formas poéticas.

Palavras-chave: imagem; poética; Maxakali.

Abstract: The image in the Maxakali verbal art: aspects of a shamanic poetics. An investigation on image in the verbal art of the Maxakali or Tikmû'ûn indigenous people, who live in four territories in the state of Minas Gerais, speak the Maxakali language, from the macro-Gê linguistic stem. Based on one of the central aspects of Maxakali spirituality - the post-mortem transformation of koxuk ("word", "soul") into yamîy ("song", "spirit") - and artistic and media manifestations typical of its rituals, connected to the mythological background, we recognize the image as one of the potentialities responsible for the creation and preservation of its poetic forms.

Keywords: image; poetics; Maxakali.

\section{Introdução}

Os Maxakali, ou Tikmû'ûn ${ }^{1}$, são um povo indígena de aproximadamente 1.500 indivíduos que habitam atualmente quatro territórios no estado de Minas Gerais.

1 Palavra Maxakali com a qual os índios se autodenominam. Seu significado aproximado é "humanidade". 
Seminômades, tradicionalmente caçadores e coletores, viviam pela região que compreende o sul da Bahia, o norte do Espírito Santo e o nordeste de Minas Gerais. Ainda falam sua língua ancestral, o Maxakali, do tronco linguístico Macro-Gê.

Os Maxakali atualmente incorporam o registro escrito alfabético como forma de manutenção e divulgação de sua cultura. Os Tikmû'ûn já publicaram vários livros, geralmente bilíngues (em Maxakali e português), sobretudo para serem usados em suas escolas. Para os livros de literatura, os escritores indígenas geralmente vão buscar em seus cantos e contos tradicionais os subsídios para a escrita.

Nos anos de 1960, Haroldo Popovich e sua esposa Francis Popovich, ambos ligados ao Summer Institute of Linguistics (SIL), conviveram com os Maxakali, aprenderam sua língua e estabeleceram um método de escrita baseado no alfabeto latino. Traduziram para o inglês alguns cantos e narrativas tradicionais Maxakali, bem como o Velho Testamento para a língua Maxakali. Por fim, alfabetizaram alguns índios. O propósito catequizador dos Popovich não vingou, mas a escrita se sedimentou entre os seus antigos alunos, tornando-se o meio para o registro de sua própria religião, arte e filosofia.

No ano de 1996, inaugurou-se o Programa de Implantação de Escolas Indígenas de Minas Gerais (PIEIMG), voltado à criação de um sistema de ensino diferenciado que proporcionasse o desenvolvimento de métodos próprios de aprendizagem para as comunidades indígenas do estado. Teve início uma produção mais sistemática de livros e outros produtos, visando ao desenvolvimento de material didático para as escolas nas aldeias. Livros de literatura se incluem neste rol. Atualmente alguns professores Maxakali já se formaram em nível universitário e continuam ensinando e produzindo livros, filmes e outros produtos de mídias modernas.

Participei desse programa inicialmente na monitoria de uma disciplina de língua portuguesa e escrita, com a finalidade de produzir publicações que pudessem se configurar enquanto material didático para as escolas indígenas. Nesse contexto, foram aprendidos os rudimentos da língua Maxakali, para que as traduções de seus cantos e narrativas fossem realizadas em parceria, sempre com a participação de um aluno indígena. Assim, o mais aprofundado conhecimento do português e os básicos conhecimentos em Maxakali da pessoa não indígena eram associados ao básico conhecimento do português e o mais aprofundado conhecimento do Maxakali do aluno indígena no trabalho de tradução.

Mais tarde, passando pelo desenvolvimento de um projeto de iniciação científica na graduação, um Mestrado e um Doutorado junto aos Maxakali, essa metodologia se aprimorou, tendo gerado materiais de subsídio, como, por exemplo, um vocabulário da língua Maxakali, já que no início dessa empreitada havia pouquíssimo material teórico sobre os Tikmû'ûn. 


\section{Koxuk/yãmîy, palavra/canto}

Koxuk é a palavra maxakali para "imagem". Ao verterem a canção popular "Índia" ao idioma Maxakali, por exemplo, para o verso "Índia, a tua imagem", os professores tikmû'ûn escreveram: "Ûhex yã'ã koxuk", em que ûhex é "mulher", que vem seguida do pronome possessivo de segunda pessoa (PEREIRA, 1992, p. 36), sendo o termo seguinte koxuk, a imagem.

A palavra aparece também na legenda para este desenho feito por Isael Maxakali.
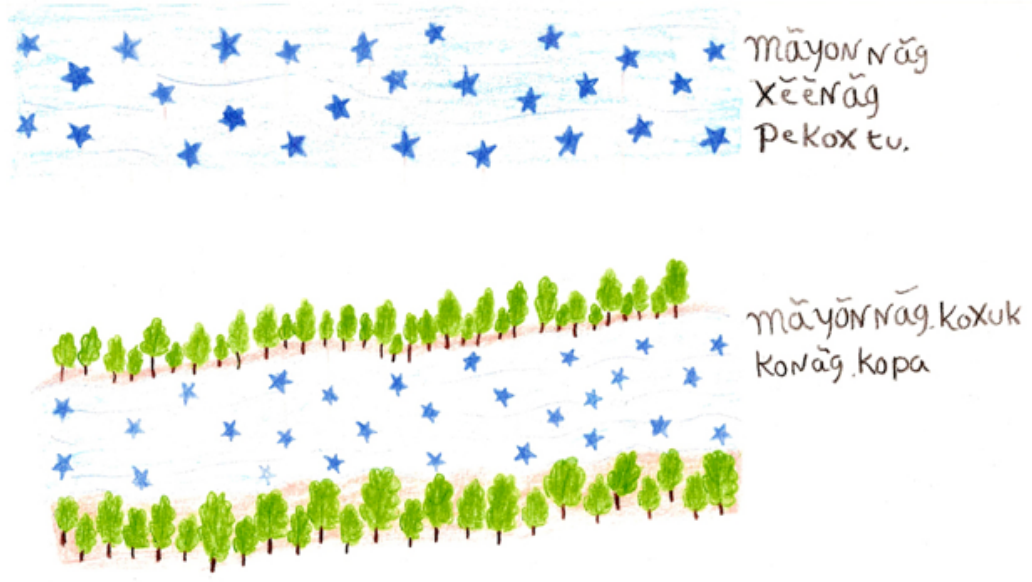

Fig. 1. Desenho de Isael Maxakali.

Para a parte de cima da ilustração, Isael escreveu: "mãyõnnãg xêênãg pekox tu"; ou seja, "estrelas verdadeiras no céu" (literalmente, "estrelas verdadeiras céu em"). Na parte de baixo, para o desenho que representa o reflexo das estrelas na água do rio, Isael escreveu: "mãyõnnãg koxuk konãg kopa", ou "reflexo das estrelas na água" (literalmente, "estrelas imagem dentro água"). Aqui a palavra ganha uma conotação de "reflexo", o que é corroborado por Alvares (1986): "o retrato, a fotografia, a sombra, a imagem refletida, também são koxuk" (p. 102).

Para Popovich (1976), "a alma do vivo é chamada koxuk" (p. 20), e cada Maxakali, brasileiros de um modo geral e índios de outras tribos, tanto homens quanto mulheres, têm seu próprio koxuk. O termo parece, pois, abarcar uma idéia de reprodução ou duplo de um corpo. Assim como geralmente dizemos que o corpo tem uma "alma".

Segundo Alvares ainda, koxuk recebe às vezes o epíteto de "palavra verdadeira", yîy xe'e em língua Maxakali (1986, p. 95)². “O koxuk é a palavra. E a palavra se transformará

2 Trata-se de uma espécie de dialeto litúrgico Maxakali, uma variação ritualística da língua Maxakali, que é dominada sobretudo pelos pajés em contexto religioso. Esta variação linguística é utilizada para a composição dos cantos tradicionais. Yîy quer dizer "língua" ou "fala". E para xe’e, Popovich (2005, p. 77) nos dá: "verdadeiro, genuíno, legítimo". 
em yãmîy e será eterna" (Idem, p. 96). Trata-se de um dos processos de transformação que constitui a pessoa Maxakali: o controle sobre o "fluxo da palavra". Como quer Alvares, "este fluxo relaciona-se de um lado, com o processo de transformação do Koxuk em Yãmîy - da palavra em canto - e, de outro, com o trânsito dos próprios Yãmîy" (Idem, p. 82). Em outro momento, é ainda Alvares que esclarece: "o destino da palavra, do koxuk, yîy xe'e, 'palavra verdadeira', é tornar-se canto, yina max (sic), 'belas palavras', através de um fluxo que reproduz o conhecimento - a tradição cultural" (Ibidem). Trocando em miúdos: a alma maxakali se constitui das palavras, tendo estas alto teor de sacralidade. Ao morrer, o ideal é que a alma Maxakali, suas palavras, se transformem em yãmîy, palavra que designa tanto seus cantos sagrados, quanto seus espíritos.

É importante lembrar que o visionamento, digamos, de tais entes, se dá no contexto ritualístico dos yãmîyxop, que Tugny (2014) define como um "evento de extrema intensidade, que é a aparição, a abertura da visão, a possibilidade de ver e de se dar a ver entre corpos que estão próximos, mas nem sempre acessíveis ao olhar. Afinal, esta é a forma da relação entre os vivos e os mortos" (p. 167).

Yãmîy é a palavra que os Maxakali usam para denominar os espíritos de seu panteão. Mortos, animais e outros elementos da natureza formam esse panteão. Alguns objetos também, como é o caso da sanfona, instrumento venerado pelos índios, provavelmente devido ao gosto que eles têm pelo forró; ou o uniforme do time de futebol Maxakali, outra paixão dos indígenas. Popovich (1976) reconhece dez grandes grupos de yãmîy e mais de duzentos subgrupos (p. 2).

É provável que possamos decompor yãmîy em yã (que denota uma "afirmação enfática") (Popovich, 2005, p. 85) e mîy (fazer). Yã está, por exemplo, no pronome de afirmação yãmûn, cuja expressão tradutória dada por Popovich seria: "É isso mesmo" (2005, p. 85). Talvez seja o yã-mîy um "fazer enfático", como uma figuração do "gesto enfático" do ritual, "a luta para encontrar uma eficácia do gesto, desfazer o signo para encontrar a ação", como nos dá a Enciclopédia Einaudi (1987, p. 27). "Artaud classificava-o como uma 'sobrevivência instintiva de uma magia'" (Ibidem). Vale lembrar que analogamente o termo grego poiesis, que em português deu origem à "poesia", tem primordialmente o sentido de "fazer" ou "criar".

Nimuendaju, outro antropólogo que aprendeu com os Maxakali, dá para a palavra yãmîy (porém grafada numa variante: nyami) o seguinte significado: "almas dos mortos" (UNKEL, 1958, p. 59). Popovich mais tarde reafirma tal acepção, escrevendo que a palavra yãmîyxop (que pode ser glosada como "reunião ou conjunto de espíritos"), que é como os Maxakali denominam seus rituais, deriva de yãmîy, e esta significa "souls of the dead" (POPOVICH, 1976, p. 2).

De acordo ainda com Popovich, "somente após a morte do corpo é (o koxuk) chamado de yãmîy" (1976, p. 20). Haveria, portanto, uma analogia entre a transformação do koxuk (alma dos vivos) em yãmîy (espírito dos mortos) e a imagem (koxuk) 
em canto (kutex). Um yãmîy seria, pois, como um koxuk cantado: uma configuração ou forma, emoldurada pelo canto:

após a morte o koxuk sofrerá um processo de alteração que o transformará em um yãmîy, distinto tanto do koxuk quanto do indivíduo ao qual pertenceu em vida. (...) A morte, portanto, opera uma transformação da pessoa, o yãmîy não pode ser considerado como um aspecto do morto ou do vivo. Ele é, essencialmente, um contrário do vivo - torna-se doravante, par cerimonial dos vivos, nos yãmîyxop (ALVARES, 1986, p. 96).

Yãmîyxop, portanto, são verdadeiros festivais, com canto, dança, comida etc., que os Maxakali realizam para entrar em contato com seus espíritos yãmîy. São verdadeiros eventos multimídia em que várias linguagens são acessadas para se alcançar o intento de se comunicar com os espíritos. Como um espetáculo de ópera, que se configura como performance, convoca várias linguagens artísticas, envolvendo narrativa, personagens, figurino, trilha sonora etc. Nessa perspectiva, os yãmîy no contexto de um yãmîyxop, seriam "personalidades nítidas, interagindo num espaço dramático" (PAGLIA, 1992, p. 77).

Os mestres de tais cerimônias performáticas são os yãmîyxoptak, palavra Maxakali para "pajé", que significa literalmente "pai do ritual" (tak é "pai"). Estes, dominando todas as técnicas da pajelança, controlam os vários regimes de linguagem que envolvem os eventos ritualísticos.

\section{"Iluminuras" cantadas}

A mesma palavra, yãmîy, que nomeia os espíritos, nomeia também seus cantos. Numa relação intrínseca com as narrativas, os cantos yãmîy funcionam, no contexto ritualístico, como espécies de iluminuras cantadas, ou ilustrações de algumas passagens das narrativas Maxakali. São objetos visuais, transmitem flashes de cenas, situações, que os "leitores" já conhecem, graças ao pano de fundo mitológico.

Nossa proposta aqui, então, é explicitar certa relação intertextual entre os cantosyãmîy Maxakali e suas narrativas correspondentes com base no que foi publicado até agora pelos professores Tikmû'ûn, bem como através da análise de materiais (traduções) desenvolvidos em aulas de Português e Literatura e oficinas para a produção de livros indígenas, ministradas por quem escreve estas linhas. Cotejando as narrativas com os cantos até agora traduzidos nesses contextos, verificamos uma relação intertextual em que alguns cantos entoados nos yãmîyxop Maxakali funcionam como construções imagéticas de cenas, situações, personagens, diálogos, dentre outros aspectos presentes nas suas histórias. Daí pensarmos em tais cantos funcionando como "iluminuras" cantadas em relação às narrativas, em que sobretudo imagens figurativas - e não grafismos - seriam privilegiadas. A comparação se justifica pelo fato de os cantos Maxakali desempenharem 
papel semelhante às figuras, desenhos ou gravuras que costumam ilustrar os livros desde os tempos das primeiras edições, o que demonstra que o visual nunca deixou de apelar ao leitor. Tampouco ao ouvinte, em termos orais.

Os cantos desempenhariam, portanto, a função de apresentar imagens ilustrativas de aspectos do texto verbal, assim como, nas típicas iluminuras, a pintura era aplicada sobretudo às letras capitulares nos pergaminhos medievais. Como quer Tugny (2011, p. 3), "os cantos dos yãmïyxopp reproduzem a experiência e a visão de algo que se passa 'aqui' na aldeia, e alhures, onde os espíritos podem se postar durante o trabalho dos cantos." ${ }^{3}$

Foi durante o processo de tradução dos cantos e das narrativas, que realizamos junto aos Maxakali, seja em oficinas, seja em sala de aula, seja em pesquisa de campo, ou na elaboração de livros, que percebemos a relação existente entre uns e outros. É, portanto, esse repertório que escolhemos para apresentar aqui: uma pequena mostra daquilo queVieira (2010) considera como "um patrimônio familiar passado de geração para geração. Um canto é sempre propriedade de um vivente, mas esta propriedade é compartilhada com um yãmiy" (p. 138).

Publicada em Hitupmã'ax (2008), páginas 139-41, uma versão em prosa da narrativa de Mãtãnãg (a índia que sai em perambulação atrás do espírito de seu marido), por exemplo, foi traduzida nas oficinas ocorridas ao longo da elaboração do livro, das quais os autores listados na folha de rosto da obra (Rafael, Pinheiro, Isael, Sueli, Mãmêy e Totó Maxakali - os dois últimos, pajés) participaram. O canto que apresentamos abaixo é cantado por Mõgmõka, o yãmîy do gavião, um dos yãmîy narradores-cantores responsável pela contação da história nos rituais yãmîyxop.
Hox hax moh
Xônnênãg ita
Xônnênãg ita
Kãyãta kã xîp
Kãyãta kã xîp
Xônnênãg ita
Xônnênãg ita
Kãyãta kã xîp
Kãyãta kã xîp
Kãyãta kã xîp
Kãyãta kã xîp
Hoix hax yaahi
Hiya a a ah iih
$\mathrm{Hi}$ ah iaaiiiih

Hox hax moh (MAXAKALI, 2008, p. 31-45).

3 Em outros trabalhos (BICALHO, 2007a, b) fica demonstrado como os cantos yãmîy atuam também como recurso mnemônico, enquanto instrumento de registro e armazenamento de conhecimento variado referente ao ambiente, às espécies etc., permitindo aos Maxakali reacessar uma infinidade de informações. 
O conteúdo cantado pelo yãmîy de Mõgmõka se resume a descrever uma cena específica da história: quando Mãtãnãg, que perseguia o rastro do espírito de seu marido, o vê com uma cobra enrolada ao pescoço atrás de uma árvore. Eis a tradução:

Hox hax moh

O pai do filhinho está em pé

O pai do filhinho está em pé

A cobra está no pescoço/ombro

A cobra está no pescoço/ombro

O pai do filhinho está em pé

O pai do filhinho está em pé

A cobra está no pescoço/ombro

cobra está no pescoço/ombro

A cobra está no pescoço/ombro

A cobra está no pescoço/ombro

Hoix hax yaahi

Hiya a a ah iih

$\mathrm{Hi}$ ah iaaiiiih

Hox hax moh

A mesma cena é assim descrita em prosa na narrativa presente em Hitupmã'ax: "Quando viu: ele estava atrás do pau da árvore. Mas estava com uma cobra enrolada no pescoço. A cobra estava enrolada no pescoço" (MAXAKALI, 2008, p. 37). O canto como que congela a imagem tida por Mãtãnãg. Mõgmõka ${ }^{4}$, que é quem canta ${ }^{5}$, se refere ao marido de Mãtãnãg por perífrase, pelo fato de ser ele o pai do filho de Mãtãnãg: "o pai do filhinho está em pé/a cobra está em seu pescoço". Uma redundância paralelística repete o enunciado à exaustão.

Completando o processo de tradução intersemiótica, os autores Maxakali ilustraram a cena com pincel e tinta para o livro:

4 Segundo Campelo (2005), que tem o foco principal de sua pesquisa no ciclo ritual de Mõgmõka, este yãmîy está associado à divisão da carne, naturalmente por ser o pássaro um grande caçador.

5 Em Hitupmã'ax há uma breve explicação de como os yãmîy se revezam na contação da história: "No canto, essa história é contada assim: Xûnîn canta e conta um pouco; Po'op (mico) canta e conta outro pouco; Mõgmõka (gavião) também canta... a dança do Mõgmõka conta um pouco também dessa história. Cada ritual pega um pedaço da história" (p. 40). Nos yãmîyxop os narradores são os yãmîy e eles narram cantando. Seus cantos projetam imagens: personagens, cenas, passagens das histórias, seus fragmentos. 


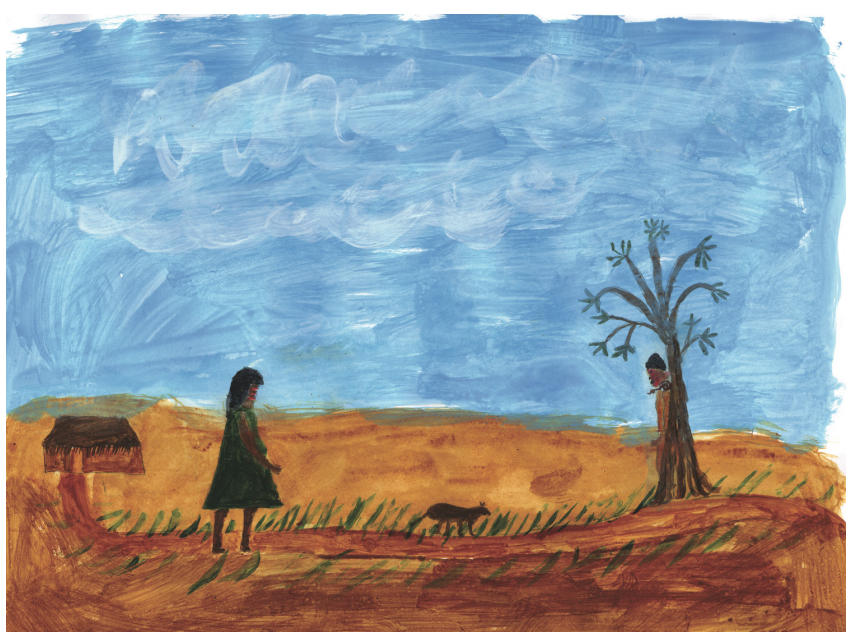

Fig. 2. Ilustração para o canto de Mõgmõka (gavião) da história de Mãtãnãg, em Hitupmã'ax (2008), p. 40-1: Mãtãnãg encontra o espírito-yãmîy de seu marido detrás de uma árvore. Ele tem uma cobra enrolada em seu pescoço.

Abaixo, a ilustração criada pelos autores do livro para o yãmîy de Mõgmõka em ação num ritual yãmîyxop a cantar-contar a história:

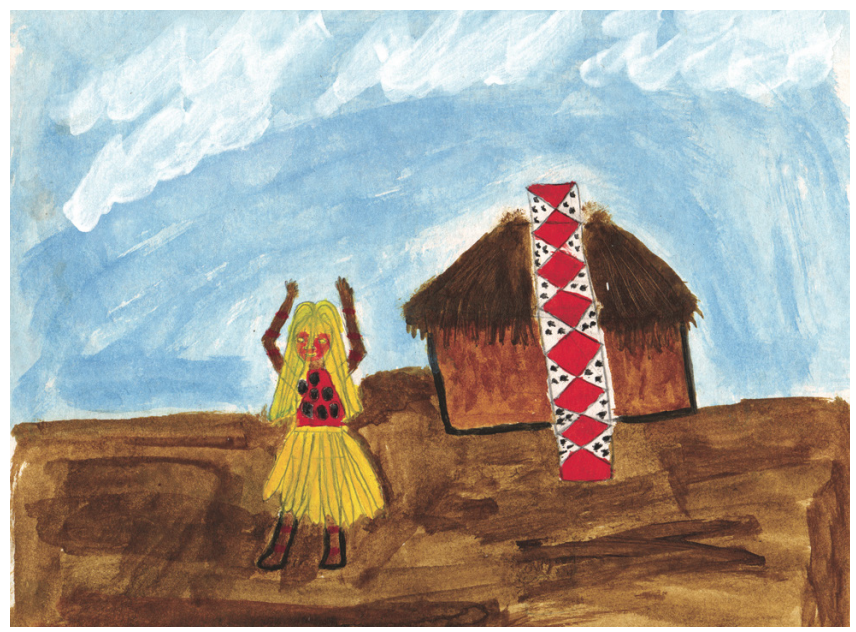

Fig. 3. Ilustração do yãmîy de Mõgmôka (gavião) durante um yãmîyxop, para o livro Hitupmãax (2008), p. 150-151: Mõgmõka é um dos narradores da história de Mãtãnãg.

O chamado "canto de Mãtãnãg" (MAXAKALI, 2008, p. 44-5) também é exemplo desse minimalismo referencial característico dos cantos yãmîy Maxakali. Da mesma maneira, ele faz referência a uma outra passagem da história de Mãtãnãg. Esta, no conto escrito 
e traduzido pelos Maxakali, na longa perambulação no encalço de seu marido, acaba por realizar uma visita à "aldeia dos yãmîyxop", ou seja, a aldeia onde vivem os yãmîy no hãmnõgnõy ${ }^{6}$ a "terra-limite" habitada pelos entes espirituais dos Tikmû'ûn:

Quando ela estava chegando na aldeia dos yãmîyxop (dos espíritos), todas as yãmîyhex viram Mãtãnãg (o nome dela era esse) e reconheceram que ela foi para lá sem morrer. Então, todas abriram suas asas e de lá saiu luz - como que relampejou debaixo do braço delas (MAXAKALI, 2008, p. 38).

O que acontece é que, quando lá chega, Mãtãnãg é avistada pelas yãmîyhex (yãmîymulher), que abrem seus braços, de cujas axilas saem raios, feito relâmpagos. Mãtãnãg como que retribui a ação, também abrindo seus braços, de onde, porém, "só saiu uma luz fraquinha", visto que ela, até este momento da narrativa ainda não havia se tornado em yãmîy, permanecendo humana, e, portanto, desprovida de grandes poderes. O canto assim sintetiza a cena:

Mãtãnãg
yãmîy mõg xop
pumi
tu yãnãm nã xip
tu yãnãm nã xip
hoix hax ya ah
hi ya aaa hi
yak aaa haii
hox hax moh

Com a consciência de que a transcrição pode também conter sua carga de criatividade, buscou-se uma disposição tipográfica inspirada pela audição do canto gravado pelos professores durante as pesquisas para o livro. Assim, cada linha do poema contém o equivalente ao que é emitido no canto a cada intervalo. Ou seja: quando há uma pausa relativamente grande, correspondentemente há uma quebra de linha. Quando a pausa é menor, principalmente estando o termo relacionado a um sintagma anterior ou posterior, como é o caso aqui de "xop", partícula de plural (ligado a "yãmîy" no início do verso),

6 Os yãmîy viveriam no hãmnõgnõy (ou hãmnõy), ou "outra-terra-diferente", a terra-limite, localizada entre a terra propriamente dita e o céu, habitada pelos entes espirituais dos Tikmû'ûn, os yãmîy.

7 Com base na audição, tanto a disposição tipográfica, quanto a sintaxe (no caso da tradução em português) buscam aqui se aproximar isomorficamente da configuração sonora do canto. Na versão em Maxakali, mantemos o designativo de "grupo" (xop) mais isolado, pois na vocalização o mesmo: ele é enfaticamente colocado à parte do resto da cadeia sonora. As quebras de linhas, como a que permite que "Mãtãnãg" e "vai" (na tradução) sejam sintagmas únicos dos versos, também respeitam as pausas do cantador. Por fim, as vocalizes são preservadas. 
mantém-se a palavra na mesma linha, porém com espaçamento proporcional à pausa. Tal disposição procura explorar uma visualidade mais expressiva para o texto impresso e sugere uma entonação para a leitura, nos moldes de experimentos como os realizados por Dennis Tedlock (1999), por exemplo.

Assim ficou a tradução:

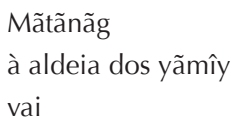

hox hax moh

De acordo com o princípio mimético, confirmado pela asserção em Hitupmã'ax, em relação a um canto para a cobra, de que, "à medida que eles cantam, os cantos imitando como a cobra faz" (MAXAKALI, 2008, p. 171), por exemplo, o segundo e terceiro versos da tradução do canto acima - "de suas axilas saem faíscas" - buscam, pela aliteração sibilante em "s" (fonema que não existe na língua Maxakali), funcionar como uma onomatopéia para a sonoridade elétrica de raios e relâmpagos.

A ilustração abaixo representa a cena. O desenho foi feito pelos professores Tikmû́ûn para o livro. As yãmîyhex encontram-se mais à direita e na parte de cima. Elas emitem raios de sob seus braços. Mãtãnãg está à esquerda no quadro, mas "de suas axilas saem faíscas".

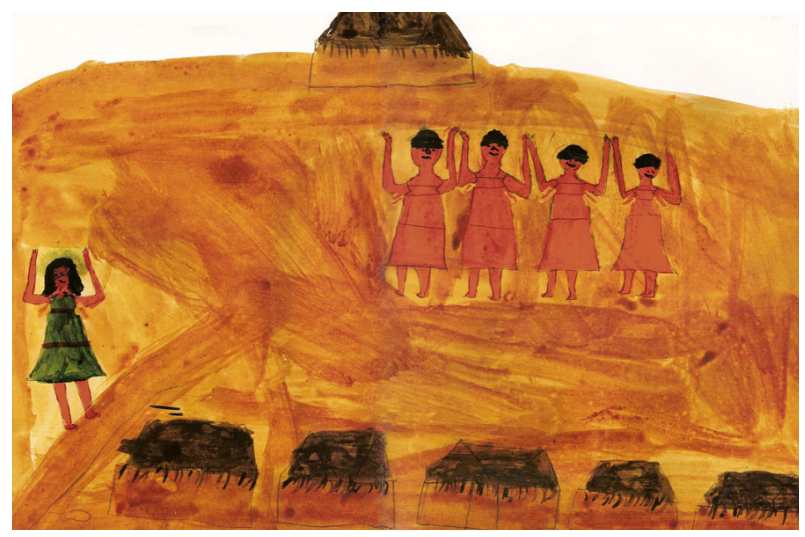

Fig. 4. Ilustração da cena cantada no "canto de Mãtãnãg" (HITUPMÃ'AX, 2008, p. 42-3): Mãtãnãg se encontra com as yãmîyhex. 
O "canto do morcego" (Xûnîn) igualmente aparece na referida publicação dos Maxakali (MAXAKALI, 2008, p. 128-129). Ele faz referência à passagem da narrativa, que fala do tempo em que "não tinha religião de morcego para cantar" (Idem, p. 50), em que um antepassado Maxakali, após ter suas bananas (tepta) comidas pelo mamífero voador, convida o yãmîy para viver na aldeia e ensinar seus cantos aos Tikmû́ûn ${ }^{8}$.

\title{
Hoo aai \\ Hoo aai \\ Hoiaá
}

Xate

Hãm ãgnut punup

Tu ãnûn yiãã

Xate

Hãm ãgnut punup

Tu ãnûn yiãã

Nãg

Pape yîkaok nã xaxip

Nãg

Pape yîkaok nã xaxip

Haiyak ooo hiai

Haiyak ooo hiai

Ooo hiai ooo hiai

A tradução foi feita na cidade de Tiradentes em setembro de 2007, com Isael Maxakali:

\author{
Hoo aai \\ Hoo aai \\ Hoiaá \\ Você \\ Vem para cantar \\ Eu pensei que você vinha
}

8 O Xûnîn é o grande yãmîy curandeiro dos Tikmû'ûn. Uma vez que o "controle do fluxo de sangue é fundamental à condição humana" (ALVARES, 1986, p. 76), é sugestivo que o mamífero hematófago seja o principal responsável pela saúde do corpo e do espírito dos Tikmû́ûn. É ele que finaliza o ritual de cura: "No final, Xûnîn manda a doença ir embora. Xûnîn canta para tirar a doença de espírito ruim que está fazendo sonhar e aí começa o final: pega a doença de espírito ruim, leva para a kuxex e manda embora" (MAXAKALI, 2008, p. 124). 
Você

Vem para cantar

Eu pensei que você vinha

Ou você não vai

Ficar em pé parado e cantar alto

Ou você não vai

Ficar em pé parado e cantar alto

Haiyak ooo hiai

Haiyak ooo hiai

Ooo hiai ooo hiai

Para ilustrar Hitupmã'ax, os professores Maxakali retrataram a imagem de dois yãmîy de Xûnîn (morcego) cantando e dançando no hãpxep, o "terreiro de religião", com a kuxex, a "casa de religião", e o mîmãnãm, o "pau de religião", ao fundo, durante um yãmîyxop.

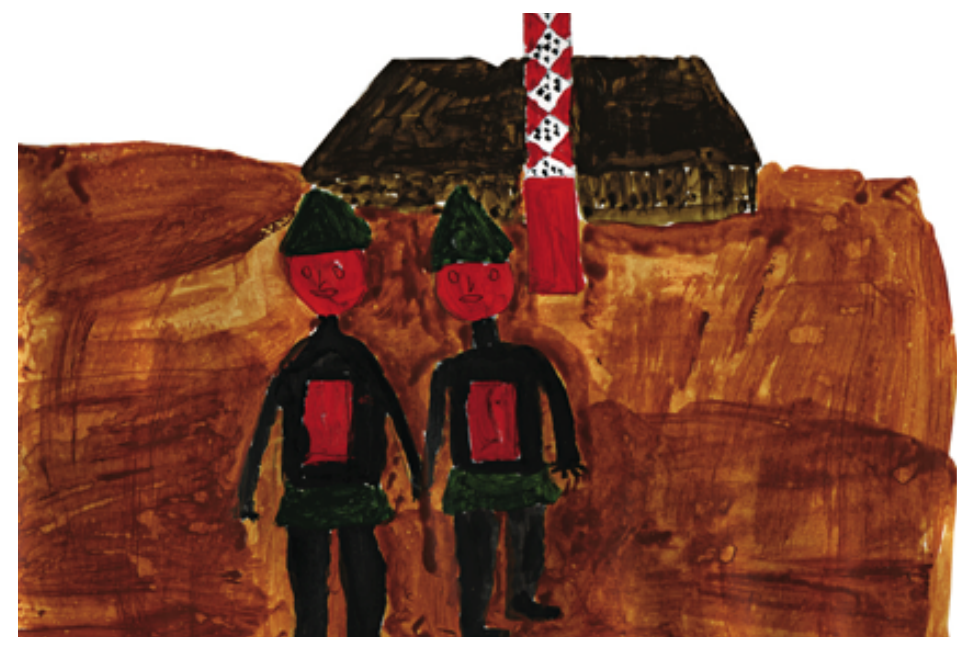

Fig. 5. Ilustração de dois Xûnîn (Morcego) para o livro Hitupmã'ax (2008), pp. 110-111.

A mesma situação fora fotografada em março de 2000 durante um yãmîyxop na aldeia de Rafael Maxakali no território Maxakali de Pradinho, no município de Bertópolis, Minas Gerais: 


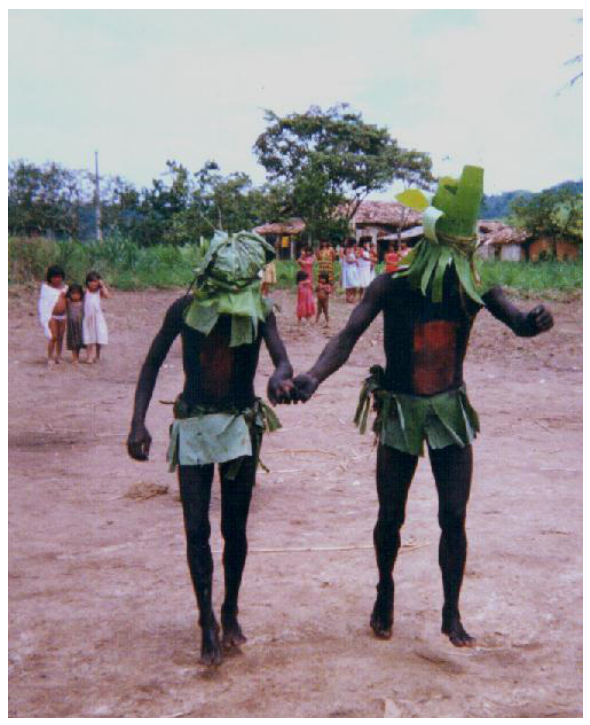

Fig. 6. Fotografia de yãmîyxop com dois Xûnîn no Pradinho em março de 2000. (Foto: Charles Bicalho)

Com base no que vem sendo posto, poderíamos tomar os cantos yãmîy enquanto iconotextos, que, segundo Louvel (2006), é quando se dá a "presença de uma imagem visual convocada pelo texto" (p. 218). Tais cantos estariam, portanto, muito mais para a iconicidade que para a discursividade. Na verdade, uma coisa completa a outra: as imagens têm um propósito narrativo - e algumas vezes apresentam micro-narrativas - na medida em que a sua sequência conta uma história, assim como os fotogramas ou planos e as cenas em um filme.

É neste sentido que vale mencionar que a ideia de imagem aqui se amplia para além da mera representação ou iconicidade. Como quer Costa (2015), no contexto Maxakali,

\begin{abstract}
imagem não se apreende satisfatoriamente como sendo a representação icônica de alguma outra coisa que não aquela com a qual nosso olhar se encontra, e que seria invisível e mais verdadeira, mas como sendo uma presença corpórea que vê e que se dá a ver, estabelece relação. Afinal, os yãmïyxop não são, ali, apenas um ícone, mas um evento, que, por sua vez, mais do que simbólico, é estético (p. 175).
\end{abstract}

Talvez possamos associar tais cantos-yãmîy aos mitemas, na acepção que Lévi-Strauss dá a esse termo, que é posteriormente reelaborado por Otávio Paz (1970): "frases ou sentenças mínimas que, por causa de sua posição no contexto, descrevem uma importante relação entre diferentes aspectos, incidentes, e personagens da história" (p. 27). Vê-se que 
os cantos Maxakali, à primeira vista tão lacônicos e sintéticos, atravessariam as narrativas Maxakali numa relação claramente intertextual com a mitologia, esse "conjunto virtual" de que fala Viveiros de Castro (1986) quanto à arte verbal dos Araweté: "A mitologia Araweté parece operar como um conjunto virtual que subjaz, na função de contexto, à proliferação cotidiana dos cantos xamanísticos" (p. 41).

O canto seguinte, como revelado pelo professor Isael Maxakali, pertence ao yãmîyxop de Moka'ok, o yãmîy "corredor"9 ${ }^{\prime}$, que tem esse epíteto porque movimenta-se rapidamente no hãpxep, o pátio sagrado, para pegar a comida oferecida pelas mulheres durante o yãmîyxop. O canto se refere a Inmõxã ${ }^{10}$, ou aos Inmõxã, e sintetiza uma passagem da história que dá título ao livro Penãhã (MAXAKALI, 2005):

De manhã cedo, ele foi olhar a armadilha para ver se pegou alguma coisa.

A armadilha pegou duas antas. Ele gritou para os Inmõxã:

- Vem pegar amãxux (anta).

E todos os Inmõxã foram correndo. Chegaram lá e tiraram os paus

da armadilha. Pegaram a anta e comeram (p. 24).

Eis a síntese cantada desta passagem:

yoooooo

haiiii

taha xop axak putix xop yõg

ãmãxux te tix tu mõnõm

taha xop axak putix xop yõg

ãmãxux te tix tu mõnõm

yoooooo

haiiii

Sua tradução é a que segue:

yoooooo

haiiii

Inmõxã, diz que os meus sobrinhos

Pegaram duas antas

Inmõxã, diz que os meus sobrinhos

Pegaram duas antas

9 A palavra moka'ok é formada pela junção do verbo mõg (ir) e o modificador de intensidade ka'ok (duro/forte/ rápido, enfim, intenso).

10 A imagem que os Maxakali fazem do Inmôxã é a de um ser com corpo todo coberto de pelo, dentes enormes e ameaçadores, garras em forma de lâminas no lugar das mãos. Sua pele é dura e instransponível aos arcos e flechas. Os únicos pontos vulneráveis do corpo de Inmôxã são seus orifícios: olhos, boca, umbigo e ânus. 
yoooooo

haiiii

O exemplo seguinte é o canto de Kokexkata (lobo guará). Kokex é a palavra para "cachorro" em Maxakali. Kata seria um termo litúrgico-ancestral para a cor vermelha, xutta em Maxakali comum. Na história, o "cachorro vermelho", metamorfoseado em homem (tihik), foge da onça (hãmgãy) subindo numa árvore. Ela, porém, consegue alcançá-lo e o devora:

ehoo hoo haii yahaii hia

kokexkata te ãtu mîm mûmõh

ãtu mîm mûmõh

ãtu mîm mûmõh

ãtu mîm mõh

kokexkata te ãtu mim mûmõh

ãtu mîm mûmõh

ãtu mîm mûmõh

ãtu mîm mõh

nûy mõy îyxaxit nûy nûy hãm tonok

nûy îmãy hã xup

nûy mõy îyxaxit nûy nûy hãm tonok

nûy îmãy hã xup

ehoo hoo haii yahaii

ehoo hoo haii yahaii

hãoo hãoo hãoo

A tradução:

ehoo hoo haii yahaii hia

Kokexkata sobe na árvore

Sobe na árvore

Sobe na árvore

Na árvore

Kokexkata sobe na árvore

Sobe na árvore

Sobe na árvore

Na árvore 
Ela agarra o homem e cai ao chão

Enquanto o come

Ela agarra o homem e cai ao chão

Enquanto o come

ehoo hoo haii yahaii

ehoo hoo haii yahaii

hãoo hãoo hãoo

A narrativa conta de um casal que foi a um local para que o marido reouvesse o seu arco-e-flecha. Quando lá chegaram, eles acenderam o fogo e dormiram, pois já era noite. A onça surgiu e atacou a mulher, comendo um pedaço de seu corpo. O marido, apavorado, correu para cima de uma árvore. A cena do canto assim se repete no texto da narrativa publicado em Penãhã (MAXAKALI, 2005):

O homem, ao ver a onça debaixo da árvore tentando subir, começou a empurrá-la com o pé, mas a onça puxou o homem.

O homem caiu. E ao cair, ele morreu e a onça comeu a sua cabeça (p. 66).

Do mesmo yãmîyxop de Moka'ok é o "canto do urucum" (nãnãnãm). Próprio de uma poética sinestésica, o canto enfatiza o odor tão característico do vegetal que produz a tintura vermelho-sangue que os participantes do yãmîyxop usam para besuntar seus corpos:

Yoooooo

Haiiii

tu ax nã xip nãnãnãm xop

'atu tu ax nãnãnãm xop

'ãtu tu ax tu ax tu ax nã xip nãnãnãm xop

'ãtu tu ax nãnãnãm xop

'ãtu tu ax nãnãnãm xop

Yoooooo

Haiiii

Em português:

Yoooooo

Haiiii

Estou com cheiro forte de urucum

Estou com cheiro forte de urucum 
Muito cheiro, muito cheiro, muito cheiro de urucum

Estou com cheiro forte de urucum

Estou com cheiro forte de urucum

Yoooooo

Haiiii

O canto se conecta à história "Inmõxã de Seu Otávio" (MAXAKALI, 2005, p. 93), publicada em Penãhã, apenas em sua versão em língua portuguesa. A cena sintetizada no canto é a que retrata o momento em que os índios montam uma armadilha para pegar Inmõxã, a fera canibal Maxakali: eles cortaram paus e fizeram um jirau por cima do rio. Dois rapazes se deitaram sobre o jirau e esperaram por Inmõxã. Quando os dois começaram a cantar, "era o sinal de que já estavam prontos" (MAXAKALI, 2005, p. 97). "Os parentes tiraram os dois rapazes da cama e os pintaram com urucum. Depois pegaram plumas e as pregaram nos corpos dos rapazes. O urucum cheirava muito forte" (Ibidem). A história segue até que os índios consigam, por um artifício, vencer Inmõxã ${ }^{11}$.

O canto seguinte também se refere à mesma história de Inmõxã. Quando os dois rapazes são trazidos para se deitarem no jirau sobre o rio para atrair Inmõxã, os "sobrinhos pequenos", putixnãg, Ihes trazem o urucum para que se pintem:

Yé yé yé yé yé yé yé

Yooooooo

Haiiii

Putixnãg xop ãpu nãnãnãm

Max hã nu xupe yãmîy hõm yãy ãna

Hõm yãy ãna

Hõm yãy ãna

Yooooooo

Haiiii

A tradução:

Yé yé yé yé yé yé yé

Yooooooo

Haiiii

Os sobrinhos pequenos trazem urucum

Trazem e entregam aos yãmîy, que se pintam

Que se pintam

Que se pintam

11 Inmõxã só morre se for flechado ou perfurado em algum dos orifícios do corpo: olhos, boca, ouvidos, umbigo ou ânus. Sua pele impenetrável faz com que o resto de seu corpo seja invulnerável. 
Yooooooo

Haiiii

O que segue, também pertencente ao yãmîyxop de Moka'ok, é o canto de Putuxkup (coruja), que se resume a pintar a imagem de um casal de corujas que canta no escuro:

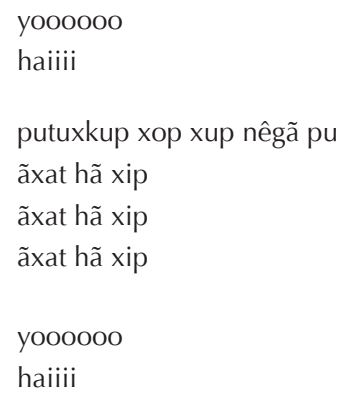

Ou:

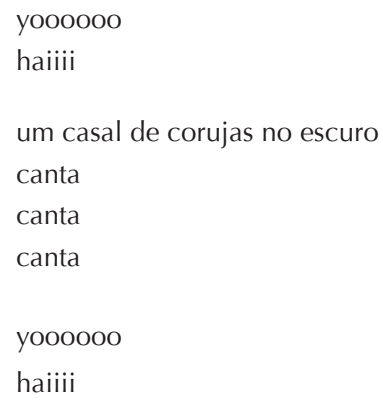

O canto de Kokexkata abaixo encontra-se também em Hitupmã'ax (MAXAKALI, 2008). Inserido no contexto da narrativa, ele faz referência ao fato de, na história, o yãmîy do lobo-guará passar a viver na kuxex (a "casa dos cantos"), onde canta toda vez que é solicitado. "Como surgiram os Maxakali" é o título que a tradução ganhou no livro.

Hahi hahi hahi hahi

Mõxatix-mõxax-xax-xeh

Mõxax-xax-xeh

Mõxat ne ãxup hahi hahi hahi

Mõxatix-mõxax-xax-xeh

Mõxax-xax-xeh

Mõxat ne ãxup hahi hahi hahi

Kõmãgkata tonoo-ok 
Segue a tradução:

Hahi hahi hahi hahi

Acordem, o dia já clareou

O dia já clareou

Venham caçar hahi hahi hahi hahi

Acordem, o dia já clareou

O dia já clareou

Venham caçar hahi hahi hahi hahi

Venham pescar (p. 26-29).

Algumas vezes o minimalismo dos cantos Maxakali chega ao paroxismo. O que segue é para o yãmîy de Kotkuphi (mandioca). Na ocasião de um yãmîyxop, de dentro da kuxex, Kotkuphi aponta sua flecha para o alto, deixando somente a sua ponta à vista de todos no "terreiro de religião" (hãpxep). Em sua literalidade o canto repete, nesta versão gravada pelos professores Tikmû'ûn, dezoito vezes o enunciado: "eu faço minha flecha sair".

Ha hi ya huk huk

Yõg pox yok yãn xumepmã

Yõg pox yok yãn xumepmã

Yõg pox yok yãn xumepmã

Yõg pox yok yãn xumepmã

Yõg pox yok yãn xumepmã

Yõg pox yok yãn xumepmã

Yõg pox yok yãn xumepmã

Yõg pox yok yãn xumepmã

Yõg pox yok yãn xumepmã

Yõg pox yok yãn xumepmã

Yõg pox yok yãn xumepmã

Yõg pox yok yãn xumepmã

Yõg pox yok yãn xumepmã

Yõg pox yok yãn xumepmã

Yõg pox yok yãn xumepmã

Yõg pox yok yãn xumepmã

Yõg pox yok yãn xumepmã

Yõg pox yok yãn xumepmã

Ha hi ya huk huk 


\section{Conclusão}

Yãmîyxop, portanto, são verdadeiros congressos que envolvem vivos e mortos, almas e espíritos. São na verdade uma série de cerimônias que apresentam analogamente uma série de cantos relativos aos grupos de yãmîy ou "souls-of-the-dead", como quer Popovich (1976). Essas séries ou grupos de cerimônias referentes aos yãmîy são a maneira pela qual os participantes narram as histórias tradicionais; desta forma encenadas nos rituais. Os yãmîyxop são a oportunidade para o intercâmbio de conhecimentos entre o mundo dos vivos e o dos mortos. Como quer Popovich ainda: "As práticas rituais são atividades em que os seres Maxakali e sobrenaturais interagem tanto para benefício mútuo quanto para danos mútuos. Cada um busca dar e receber certos benefícios, ou infligir ferimentos e se defender (1976, p. 23) $)^{12}$

Os yãmîy trazem seus conhecimentos e os dão de presente aos humanos. Estes, por sua vez, procuram presentear os espíritos, oferecendo suas comidas preferidas e cantando entusiasticamente como forma de lhes homenagear. De tal interação é que depende a sobrevivência da cultura Tikmû'ûn. Todo o modo de vida Maxakali advém daí. Alvares (1986) nos dá uma ideia dessa importância:

o conhecimento pertence aos espíritos e os homens só lhe têm acesso através da realização dos yãmîyxop. Isto é, trazendo os yãmîy para cantarem e para habitarem novamente entre os vivos. É, portanto, a relação entre os espíritos e almas e os humanos que permite a atualização do conhecimento (p. 97).

O signo literário Tikmû'ûn é, por excelência, sensório (sonoro e/ou visual). Diante dos aspectos aqui levantados, pode-se dizer que a literatura Maxakali ou Tikmû́ûn guarda traços alinhados com certa tradição que vê na poesia mais afinidade com a pintura ou a música do que propriamente com a literatura. Ut pictura poiesis, a concepção da antiguidade que estabelece essa relação, e que atravessa a modernidade em poetas como Arthur Rimbaud, chegando até a América com Ezra Pound e seu "imagismo", é a mesma concepção que subjaz na arte dos poetas concretos brasileiros, que levam ao extremo os procedimentos para se extrair da palavra o que ela tem de imagem. Parece provável que hoje a teoria literária ou poética, com base em tal tradição, reconheça na poesia indígena mais uma afirmação dessa característica. Não à toa, o concretista Haroldo de Campos defendia a incorporação à literatura brasileira da tradição poética em língua tupi (deve-se reivindicá-la em todas as línguas indígenas) e em seu Crisantempo - no espaço curso nasce um (2004) presta uma homenagem á literatura ameríndia ao "reimaginar" em língua portuguesa poemas escritos em nahuátl (a língua ancestral dos Astecas mexicanos).

12 "Ritual practices are activities in which the Maxakali and supernatural beings interact either for mutual benefict or mutual harm. Each seeks either to give and receive certain benefits, or to inflict injuring and defend himself." 
Charles A. P. Bicalho é professor da Universidade do Estado de Minas Gerais, unidade Claudio, e doutor em Estudos Literários pela UFMG. Tem especialização em Pós-produção para cinema eTV e Master of Arts em Estudos Literários pela Universidade do Novo México (UNM), nos Estados Unidos.

charlesbicalho@gmail.com

\section{Referências}

ALVARES, M. M. Yãmîy, os espíritos do canto: a construção da pessoa na sociedade Maxakali. Mestrado em Antropologia Social. Instituto de Filosofia e Ciências Humanas da Universidade Estadual de Campinas, Campinas, 1986.

ARBEX, M. (Org.). Poéticas do visível: ensaios sobre a escrita e a imagem. Belo Horizonte: Programa de Pós-Graduação em Letras: Estudos Literários/FALE/UFMG, 2006.

BICALHO, C. Koxuk: a imagem do yãmîy na poética maxakali. Tese de doutorado. Programa de Pós-Graduação em Estudos Literários (Pós-Lit). Faculdade de Letras, UFMG. Belo Horizonte, 2010.

. Yãmîy maxakali: um gênero nativo de poesia. Revista Aletria. Programa de Pós-Graduação em Estudos Literários da Faculdade de Letras da UFMG, v. 16. Belo Horizonte, 2007a (p. 119-132).

Ideograma e pensamento selvagem: a arte e a ciência do yãmîy Maxakali. Revista Gragoatá. Programa de Pós-Graduação em Letras do Instituto de Letras da UFF, v. 12, n. 23, p. 168-187. Niterói, $2007 \mathrm{~b}$

CAMPELO, D. F. G. Notas sobre a música e o universo mitológico Maxakali. Anais do Décimo Quinto Congresso da Associação Nacional de Pesquisa e Pós-Graduação em Música - ANPPOM, 2005. p. 749-57.

CAMPOS, H. de. Crisantempo: no espaço curvo nasce um. Coleção Signos 24. São Paulo: Perspectiva, 2004.

COSTA, A. C. E. Cosmopolíticas, olhar e escuta: experiências cine-xamânicas entre os Maxakali. Dissertação de Mestrado em Antropologia Social no Programa de Pós-Graduação em Antropologia da UFMG. Belo Horizonte, 2015

EINAUDI, Enciclopédia. Oral/Escrito/Argumentação, v. 11. Maia, Portugal: Imprensa Nacional Casa da Moeda, 1987.

LOUVEL, L. A descrição 'pictural': por uma poética do iconotexto. In: ARBEX, M. (Org.) Poéticas do visível: ensaios sobre a escrita e a imagem. Belo Horizonte: Programa de Pós-Graduação em Letras: Estudos Literários, Faculdade de Letras da UFMG, 2006. p. 191-220.

MAXAKALI, P. Hitupmã'ax/Curar. Belo Horizonte: Faculdade de Letras/UFMG; Edições Cipó Voador, 2008.

. Penãhã: livro de Pradinho e Água Boa. Belo Horizonte: Faculdade de Letras da UFMG/CGEEI/ SECAD/MEC, 2005.

PAGLIA, C. Personas sexuais: arte e decadência de Nefertite a Emily Dickinson. Tradução de Marcos Santarrita. São Paulo: Companhia das Letras, 1992. 
PAZ, O. Claude Lévi-Strauss: an introduction. Translated from the Spanish by J. S. Bernstein and Maxine Bernstein. Ithaca and London: Cornell U. P., 1970. (Translated from Claude Lévi-Strauss o el nuevo festín de Esopo).

PEIRCE, C. S. Semiótica. $3^{\text {a }}$ ed. Tradução: José Teixeira Coelho Neto. São Paulo: Perspectiva, 2005.

PEREIRA, D. G. Alguns Aspectos Gramaticais da Língua Maxakali. Mestrado em Linguística. Universidade Federal de Minas Gerais, Belo Horizonte, 1992.

POPOVICH, A. H. Maxakali Supernaturalism. Summer Institute of Linguistics, 1976.

\& POPOVICH, F. B. Dicionário Maxakalí-Português/Glossário Português-Maxakali. Primeira Edição Online. Sociedade Internacional de Linguística (SIL). Cuiabá, MT, dezembro de 2005.

TEDLOCK, D. Finding the center: the art of the Zuni storyteller. 2nd editon. Lincoln and London: University of Nebraska Press, 1999.

TUGNY, R. Reverberações entre cantos e corpos na escrita Tikmû'ûn. Revista Transcultural de Música, n. 15, 2011. Acesso: mar. 2018 https://www.sibetrans.com/trans/public/docs/trans_15_18_Pereira.pdf

Filhos-imagens: cinema e ritual entre os Tikmû'ûn. Revista Devires. Cinema e Humanidades. v. 11, n. 2, p. 154-179. Belo Horizonte, jul./dez. 2014.

UNKEL, C. N. Índios Machacari. Revista de Antropologia, v. 6, n. 1, p. 53-61, São Paulo, junho de 1958.

VIEIRA, M. G. A gente não faz mais guerra, agora a gente está pensando: xamanismo e educação escolar entre os Maxakali. Revista Cadernos de Campo, v. 19, n. 19, p. 135-150. São Paulo, 2010.

VIVEIROS DE CASTRO, E. Araweté: os deuses canibais. Rio de Janeiro: Jorge Zahar, 1986. 